\title{
Article \\ Ecological Role of Volatile Organic Compounds Emitted by Pantoea agglomerans as Interspecies and Interkingdom Signals
}

\author{
Maria Vasseur-Coronado ${ }^{1,2,3,4}$, Anthi Vlassi ${ }^{5}$, Hervé Dupré du Boulois ${ }^{3}$, Rainer Schuhmacher ${ }^{5} \mathbb{D}^{\circ}$, \\ Alexandra Parich ${ }^{5}$, Ilaria Pertot ${ }^{1,6}$ and Gerardo Puopolo ${ }^{1,6, *}$ \\ 1 Research and Innovation Centre, Department of Sustainable Agro-Ecosystems and Bioresources, \\ Fondazione Edmund Mach, Via E. Mach 1, 38098 San Michele all'Adige, Italy; mco@scientia.be (M.V.-C.); \\ ilaria.pertot@unitn.it (I.P.) \\ 2 Department of Civil, Environmental and Mechanical Engineering, University of Trento, via Mesiano 77, \\ 38123 Trento, Italy \\ 3 De Ceuster Meststoffen NV (DCM), Bannerlaan 79, 2280 Grobbendonk, Belgium; hddb@dcm-info.com \\ 4 Scientia Terrae Research Institute, Fortsesteenweg 30A, 2860 Sint-Katelijne-Waver, Belgium \\ 5 Department of Agrobiotechnology (IFA-Tulln), Institute of Bioanalytics and Agro-Metabolomics, \\ University of Natural Resources and Life Sciences, Vienna (BOKU), Konrad-Lorenz Straße 20, \\ 3430 Tulln, Austria; anthi.vlassi@boku.ac.at (A.V.); rainer.schuhmacher@boku.ac.at (R.S.); \\ alexandra.parich@boku.ac.at (A.P.) \\ 6 Center Agriculture Food Environment (C3A), University of Trento, via E. Mach 1, \\ 38098 San Michele all'Adige, Italy \\ * Correspondence: gerardo.puopolo@unitn.it
}

Citation: Vasseur-Coronado, M.;

Vlassi, A.; Boulois, H.D.d.;

Schuhmacher, R.; Parich, A.; Pertot, I.;

Puopolo, G. Ecological Role of

Volatile Organic Compounds Emitted

by Pantoea agglomerans as Interspecies

and Interkingdom Signals.

Microorganisms 2021, 9, 1186.

https://doi.org/10.3390/

microorganisms 9061186

Academic Editor:

Dilfuza Egamberdieva

Received: 4 May 2021

Accepted: 29 May 2021

Published: 31 May 2021

Publisher's Note: MDPI stays neutral with regard to jurisdictional claims in published maps and institutional affiliations.

Copyright: () 2021 by the authors. Licensee MDPI, Basel, Switzerland. This article is an open access article distributed under the terms and conditions of the Creative Commons Attribution (CC BY) license (https:// creativecommons.org/licenses/by/ $4.0 /)$.

\begin{abstract}
Volatile organic compounds (VOCs) play an essential role in microbe-microbe and plantmicrobe interactions. We investigated the interaction between two plant growth-promoting rhizobacteria, and their interaction with tomato plants. VOCs produced by Pantoea agglomerans MVC 21 modulates the release of siderophores, the solubilisation of phosphate and potassium by Pseudomonas (Ps.) putida MVC 17. Moreover, VOCs produced by P. agglomerans MVC 21 increased lateral root density (LRD), root and shoot dry weight of tomato seedlings. Among the VOCs released by $P$. agglomerans MVC 21, only dimethyl disulfide (DMDS) showed effects similar to P. agglomerans MVC 21 VOCs. Because of the effects on plants and bacterial cells, we investigated how P. agglomerans MVC 21 VOCs might influence bacteria-plant interaction. Noteworthy, VOCs produced by P. agglomerans MVC 21 boosted the ability of Ps. putida MVC 17 to increase LRD and root dry weight of tomato seedlings. These results could be explained by the positive effect of DMDS and P. agglomerans MVC 21 VOCs on acid 3-indoleacetic production in Ps. putida MVC 17. Overall, our results clearly indicated that P. agglomerans MVC 21 is able to establish a beneficial interaction with Ps. putida MVC 17 and tomato plants through the emission of DMDS.
\end{abstract}

Keywords: VOC; plant growth-promoting rhizobacteria; Pantoea agglomerans; Pseudomonas putida; tomato seedlings; dimethyl disulfide

\section{Introduction}

Plant growth is affected significantly by the intimate interactions established with microorganisms residing in the rhizosphere and, indirectly, on the interactions among these microorganisms. The rhizosphere is indeed a hot spot where microbe-microbe and plant-microbe interactions occur [1,2]. This ecological niche is occupied by a plethora of microorganisms that establish complex interactions with neighbouring microflora, microfauna and plant roots via production of secondary metabolites enabling them to respond and adapt to environmental changes [3].

Ranging from $10^{6}$ to $10^{12}$ gene copy numbers/g of sample, bacteria represent the most abundant class of microorganisms residing in soil, plant roots, and rhizosphere [4]. In these regions, bacteria cells regulate their activities through quorum sensing (QS) systems, based 
on the emission and perception of communication signals [5,6]. These communication signals play an important role in the intraspecies interactions regulating, for example, biofilm formation, biosynthesis of antibiotics, and plasmid conjugal transfer $[7,8]$. They are also involved in the interspecies interactions by mediating competition and/or cooperativity among bacteria [9-11], but they can be sensed also by (micro)organisms belonging to other kingdoms [12]. Among chemical communication signals, $\mathrm{N}$-acyl homoserine lactones (AHLs) received most of the attention so far $[13,14]$. As AHLs are produced by numerous bacterial species residing in the rhizosphere, they may act as interspecies signals modulating the behaviour of bacterial co-existing populations [9]. At the same time, AHLs can also constitute interkingdom signals and their perception by plants may trigger systemic plant resistance and/or affect plant growth and development [15-17].

Volatile organic compounds (VOCs) are a new class of interspecies and interkingdom signal compounds [18]. They are small molecules $(<400 \mathrm{Da})$ belonging to different chemical classes that can evaporate and diffuse easily through air- and water-filled pores [19]. These properties make VOCs ideal signal candidates in the interactions with plant roots. Bacteria were found to produce more than 1000 VOCs and non-organic volatile compounds [20] and some of them increase yield and quality of crop plants. In fact, bacterial VOCs may modulate several physiological processes such as photosynthesis, plant hormone balance [21], uptake of nutrients from soil [22,23], systemic plant resistance mechanisms [24], and tolerance to soil salinization and drought stress $[25,26]$. At the same time, bacterial VOCs may act as interspecies communication signals playing a relevant role in the cooperation and competition among soilborne bacteria that are not in contact to each other [27]. Indeed, bacterial VOCs may can act as signal molecules between bacteria [28,29] and inhibit or promote the growth of other bacteria [30-32]. While the involvement of these chemical compounds in the complex interaction webs of the rhizosphere is largely acknowledged, their specific ecological roles are still far from being fully understood.

As bacterial VOCs are thought to be interspecies and interkingdom communication signals, the aim of our study was to clarify the interaction between two plant growthpromoting rhizobacteria (PGPR) and tomato plants, by analysing the role of the bacterial VOCs in microbe-microbe interaction and, in parallel, their plant growth-promoting effect.

\section{Materials and Methods}

\subsection{Microorganisms and Plants}

The bacterial strains used in this work, Pantoea agglomerans MVC 21 and Pseudomonas (Ps.) putida MVC 17, previously isolated from tomato rhizosphere [33], were stored at length in glycerol $40 \%$ at $-80{ }^{\circ} \mathrm{C}$ and routinely grown on Nutrient Agar (NA, Neogen, Miami, FL, USA) in not split Petri dishes ( $90 \mathrm{~mm}$ diameter). To prepare bacterial cell suspensions, bacterial strains were grown in five $\mathrm{mL}$ of Nutrient Broth (NB, Oxoid, Basingstoke, UK) at $27^{\circ} \mathrm{C}$ on an orbital shaker $(200 \mathrm{rpm})$. After $24 \mathrm{~h}$, a volume of one $\mathrm{mL}$ of bacterial cell suspensions was centrifuged (13,000 rpm, $2 \mathrm{~min}$ ) and pellets were suspended in $\mathrm{NaCl}$ solution $(0.85 \% w / v)$ to a final optical density at $600 \mathrm{~nm}\left(\mathrm{~A}_{\mathrm{OD} 600 \mathrm{~nm}}\right)$ of 0.1 corresponding to $\simeq 1 \times 10^{7}$ colony forming units (CFU) $/ \mathrm{mL}$ and used in all the experiments, except when otherwise indicated.

Tomato seeds (Solanum lycopersicum var. Moneymaker; Justseed, Wrexham, UK), surface sterilised according to [33], were sown on not split Petri dishes containing $25 \mathrm{~mL}$ of Murashige and Skoog Agar medium (MS, [34]) supplemented with 1.5\% (w/v) of sucrose (Sigma-Aldrich, St. Louis, MO, USA). Dishes were sealed with double layer of Parafilm tape and kept in a growth chamber $\left(25 \pm 1{ }^{\circ} \mathrm{C} ; 70 \pm 10 \%\right.$ relative humidity $(\mathrm{RH}) ; 16 \mathrm{~h}$ photoperiod) for $96 \mathrm{~h}$. Four-day-old tomato seedlings were used in all the experiments, except when otherwise indicated. 


\subsection{Evaluation of Compatibility between Pantoea agglomerans MVC 21 and Pseudomonas putida MVC17}

A volume of $10 \mu \mathrm{L}$ of P. agglomerans MVC 21 cell suspension was spot-inoculated onto NA in not split Petri dishes. Subsequently, $10 \mu \mathrm{L}$ of Ps. putida MVC 17 cell suspension was spot-inoculated at one $\mathrm{cm}$ distance from P. agglomerans MVC 21 (Figure S1A). Similarly, the compatibility between the two strains was tested in split Petri dishes $(92 \mathrm{~mm})$ with two compartment and ventilation cams (Sarstedt, Nümbrecht, Germany) following the same procedure. The difference consisted in the presence of the separation border of the split Petri dish located in the middle of the $1 \mathrm{~cm}$ distance occurring between the two bacterial strains (Figure S1B). Once bacterial strains were spot-inoculated, not split and split Petri dishes were sealed with double layer of Parafilm tape (Beims, Neenah, WI, USA). Monocultures consisting of NA contained in not split and split Petri dishes inoculated solely with P. agglomerans MVC 21 or Ps. putida MVC 17 were used as untreated controls. After $48 \mathrm{~h}$ incubation at $25^{\circ} \mathrm{C}$, dishes were photographed with Bio-Rad Quantity One software implemented in a Bio-Rad Geldoc system (Bio-Rad Laboratories, Inc., Hercules, CA, USA). Digital images were subsequently used to measure the area of bacterial strain macrocolonies using the software ImageJ1.50i [35].

To determine the quantity of P. agglomerans MVC 21 and/or Ps. putida MVC 17 viable cells residing in the macrocolony, plugs (five $\mathrm{mm}$ diameter) were sampled from each macrocolony and transferred into sterile $1.5 \mathrm{~mL}$ microcentrifuge tubes containing one $\mathrm{mL}$ of sterile $\mathrm{NaCl}$ solution $(0.85 \%)$. After $1 \mathrm{~h}$ incubation at $25^{\circ} \mathrm{C}$ on an orbital shaker (200 rpm), bacterial cell suspensions were serially diluted (from $10^{-1}$ to $10^{-7}$ ) and those dilutions were plated onto 1/10 Tryptic Soy Agar (TS broth (Oxoid, UK), Agar Technical no.2 16 g/L (Oxoid, UK)). Once inoculated, Petri dishes were maintained at $25{ }^{\circ} \mathrm{C}$ and the developed CFUs were counted after $48 \mathrm{~h}$ incubation.

To assess the quantity of cell residing in the macrocolony, the following formula was applied

$$
\begin{aligned}
& \text { Viable cells residing in macrocolony }\left(\log _{10}\right)= \\
& \frac{\text { Counted CFU } \times \text { Surface area of the macrocolony }}{\text { Surface area of the } 5 \mathrm{~mm} \text { plug }}
\end{aligned}
$$

Six replicates (Petri dishes) were used for each treatment, and the experiment was repeated.

\subsection{Assessment of the Interaction Effect on Plant Growth-Promoting Activities of Pantoea agglomerans MVC 21 and Pseudomonas putida MVC 17}

The ability of the tested bacterial strains to chelate iron and to solubilise phosphate and potassium was assessed in monoculture and in pairwise combination both on not split and split Petri dishes. Chrome Azurol (CAS) agar, National Botanical Research Institute's phosphate (NBRIP) medium, and Aleksandrow Agar (AA, HiMedia GmbH, Germany) were used respectively to assess iron chelation and solubilisation of phosphate and potassium according to [33]. In the case of not split Petri dishes, bacterial cell suspensions were spot-inoculated onto AA, CAS agar and NBRIP according to the procedure reported above. In the case of split Petri dishes, one compartment was filled with NA $(25 \mathrm{~mL})$ and the second one was filled either with five $\mathrm{mL}$ of AA, or CAS agar or NBRIP, respectively. A volume of $10 \mu \mathrm{L}$ of P. agglomerans MVC 21 and/or Ps. putida MVC 17 cell suspension was spot-inoculated onto the compartment containing NA. Not split and split Petri dishes were sealed with a double layer of Parafilm tape and incubated at $25^{\circ} \mathrm{C}$. After $48 \mathrm{~h}$, a volume of five $\mu \mathrm{L}$ of P. agglomerans MVC 21 and/or Ps. putida MVC 17 cell suspension was spot-inoculated onto AA, CAS agar and/or NBRIP contained in the second compartment. Bacterial strains grown as monocultures on AA, CAS agar, and NBRIP were used as untreated controls in the case of not split Petri dishes. Split Petri dishes having the compartment containing NA not inoculated with any bacterial strain were used as untreated controls. 
Once inoculated, dishes containing CAS agar were incubated at $25^{\circ} \mathrm{C}$ for $24 \mathrm{~h}$ whereas dishes containing AA and NBRIP were incubated at $25^{\circ} \mathrm{C}$ for $96 \mathrm{~h}$. After each incubation period, not split and split Petri dishes were photographed with Bio-Rad Quantity One software implemented in a Bio-Rad Geldoc system (Bio-Rad Laboratories, USA). In the case of split Petri dishes, ImageJ1.50i was used to measure the area of orange haloes (release of siderophores) and clarification haloes (solubilisation of phosphate and potassium) formed around bacterial macrocolonies. In the case of not split Petri dishes, the haloes were measured on the macrocolony side without contact with the interacting bacterial strain (pairwise combination) or on the corresponding side in the untreated control. For each treatment, six replicates (Petri dishes) were used and the experiment was repeated.

2.4. Evaluation of the Effect of VOCs Emitted by Pantoea agglomerans MVC 21 and Pseudomonas putida MVC 17 on Tomato Plant Growth

A volume of $20 \mu \mathrm{L}$ of P. agglomerans MVC 21 and/or Ps. putida MVC 17 cell suspension was spot-inoculated into NA contained in one compartment of split Petri dishes. Subsequently, split Petri dishes were sealed with a double layer of Parafilm tape and incubated at $25{ }^{\circ} \mathrm{C}$. After $48 \mathrm{~h}$, three tomato seedlings were placed in the second compartment containing MS medium (25 mL). Tomato seedlings exposed to NA only were used as untreated control. Dishes were sealed with a double layer of Parafilm tape and incubated in a growth chamber $\left(25 \pm 1{ }^{\circ} \mathrm{C} ; 70 \pm 10 \% \mathrm{RH} ; 16 \mathrm{~h}\right.$ photoperiod). After 10 days, lateral root density (LRD; number of lateral roots/length main root $(\mathrm{cm})$ ) were determined according to [36]. Plant dry weight (mg) was determined after overnight incubation at $65{ }^{\circ} \mathrm{C}$ in an incubator. Four replicates (split Petri dishes) were used for each treatment and the experiment was repeated.

\subsection{Metabolite Profiling of VOCs Emitted by Pantoea agglomerans MVC 21}

2.5.1. Preparation of Samples for Headspace Analysis

For headspace volatile analysis, P. agglomerans MVC 21 was inoculated into headspace (HS) vials according to [37] with some modifications. Briefly, five mL of sterilized NA was poured into sterile HS vials (20 mL, La-Pha-Pack, Langerwehe, Germany) and placed horizontally under the laminar flow cabinet. The HS vials were left open overnight at room temperature under the laminar flow cabinet to avoid water condensation. A volume of $20 \mu \mathrm{L}$ of P. agglomerans MVC 21 cell suspension was spot-inoculated onto NA and the HS vials were left to dry under the laminar flow cabinet for at least $2 \mathrm{~h}$. HS vials containing only NA were used as untreated controls in order to distinguish the VOCs emitted by the culture medium. Each HS vial was then tightly sealed with sterile metal caps containing $1.3 \mathrm{~mm}$-silicone/PTFE septa (La-Pha-Pack) and incubated at $25^{\circ} \mathrm{C}$ for $144 \mathrm{~h}$ before GC-MS measurement. The $144 \mathrm{~h}$ time point was chosen as it showed the richest VOC profile of $P$. agglomerans MVC 21 growing in HS vials.

\subsubsection{Headspace GC-MS Analysis}

The analysis of VOCs emitted by P. agglomerans MVC 21 was performed according to the procedure described by [38]. Briefly, a gas chromatograph (GC) was coupled to a mass selective detector (MSD). The GC-MSD was equipped with a multi-purpose autosampler (MPS), a dynamic headspace system (DHS, Gerstel), a thermal desorption unit (TDU) and a cooled injection system (CIS) unit. Following a 15 min incubation in the DHS at $27^{\circ} \mathrm{C}$, VOCs were dynamically collected from the samples and trapped on a $2 \mathrm{~cm}$ TENAX trap at $30{ }^{\circ} \mathrm{C}$. The tenax tube was subsequently dried to remove potentially trapped water. VOCs were then thermally desorbed by heating the TDU unit from $30{ }^{\circ} \mathrm{C}$ to $230{ }^{\circ} \mathrm{C}$ at a rate of $60{ }^{\circ} \mathrm{C} / \mathrm{min}$, followed by a hold time of $5 \mathrm{~min}$ and transferred to the GC-MS column by cooled injection in the splitless mode (from $-150{ }^{\circ} \mathrm{C}$ to $250{ }^{\circ} \mathrm{C}$ at a rate of $2{ }^{\circ} \mathrm{C} / \mathrm{s}$, hold time $6 \mathrm{~min})$. The chromatographic separation was performed on a HP-MS (5\% phenyl methylsiloxane) column $(30 \mathrm{~m} \times 0.25 \mathrm{~mm} \times 0.25 \mu \mathrm{m})$. The GC oven temperature program was the following: $35^{\circ} \mathrm{C}$ for $2 \mathrm{~min}$, raised to $200^{\circ} \mathrm{C}$ at $5{ }^{\circ} \mathrm{C} / \mathrm{min}$ (hold time $1 \mathrm{~min}$ ) increased 
from $200{ }^{\circ} \mathrm{C}$ to $250{ }^{\circ} \mathrm{C}$ at $20{ }^{\circ} \mathrm{C} / \mathrm{min}$ (hold time $5 \mathrm{~min}$ ). Helium was used as carrier gas at a flow rate of one $\mathrm{mL} / \mathrm{min}$.

The open-source software MetaboliteDetector [39] version-3.1. (http:/ / metabolitedetector. tu-bs.de/, accessed on 29 May 2021) was used to process the data. The initial parameters used were peak threshold 5.00, peak height 5.00, bins/scan 10 and deconvolution width (scan) 5.00. For compound annotation and identification, a similarity score was calculated with the MetaboliteDetector program by combining the retention index (RI) fit and the similarity of the compound mass spectra. A similarity score $\geq 0.8$ with $\Delta \mathrm{RI}<5.00$ was required. For identification of compounds the spectra and RI values were compared to authentic standards measured under the same GC-MS conditions. Compound annotation was based on comparisons with entries from NIST 14 library (National Institute of Standards and Technology, USA, http:/ / www.nist.gov, accessed on 29 May 2021). The RI was calculated by the software by comparing the experimental retention time to those of a series of n-alkanes (C8-C25) measured under the same chromatographic conditions. Identification levels were assigned according to the criteria described by [40].

\subsubsection{Preparation of Volatile Organic Compound Solutions for Functional Assays}

Pure 2-phenylethyl alcohol (2PEA), 3-methyl-1-butanol (3M1B) and dimethyl disulfide (DMDS), were purchased (Sigma-Aldrich, USA) and tested for their individual effects on tomato plant growth and on the ability of Ps. putida MVC 21 to chelate iron, produce indole-3-acetic Acid (IAA) and solubilise phosphate and potassium.

To determine the dosage to be used for the VOC-mediated functional assays, the amount of each VOC emitted by P. agglomerans MVC 21 in the HS vials was estimated as

$$
\begin{gathered}
\text { Absolute amount of each standard }(\mu g)= \\
\left(\begin{array}{c}
\text { Concentration of each standard }(\mu g / \mu L) \times \\
\text { Volume }(\mu L) \text { of standard used in } \mathrm{HS} \text { vial }
\end{array}\right) \\
\text { Calculation factor of each standard }(\mu \mathrm{g} / \text { Area })= \\
\text { Absolute amount of each standard }(\mu \mathrm{g}) \\
\text { Average peak area measured for each standard } \\
\text { Estimated amount of compound }(\mu \mathrm{g})= \\
\left(\begin{array}{c}
\text { Average peak area measured for VOC in the } \mathrm{GC}-\mathrm{MS} \text { chromatogram } \\
\times \text { Calculation factor of each compound }
\end{array}\right)
\end{gathered}
$$

Stock solutions with a concentration of $0.02 \mathrm{ng}, 0.2 \mathrm{ng}, 2 \mathrm{ng}$, and $20 \mathrm{ng}$ per split Petri dish of DMDS; $0.09 \mathrm{ng}, 0.9 \mathrm{ng}$, and $9 \mathrm{ng}, 90 \mathrm{ng}$ per split Petri dish of 2PEA and $9 \mathrm{ng}$, $90 \mathrm{ng}$ and $900 \mathrm{ng}, 9000 \mathrm{ng}$ per split Petri dish of 3M1B were prepared by serial dilution using ethanol (Merck KGaA, Darmstadt, Germany) to test the effects of pure VOC on plant growth-promoting trait or methanol (Merck, Darmstadt, Germany) to test the effects of pure VOC on tomato plant growth. Ethanol and methanol were used as solvents since they are reported to be nontoxic to bacteria and plants respectively [41,42].

2.6. Evaluation of the Effect of Pure VOCs on Tomato Plant Growth and Plant Growth-Promoting Traits of Pseudomonas putida MVC 17

In all experiments, a filter paper ( $90 \mathrm{~mm}$, VWR) was placed into one compartment of split Petri dishes and inoculated with $20 \mu \mathrm{L}$ of the stock solutions of 2PEA, 3M1B, and DMDS at different concentrations. In the case of the effect on tomato plant growth, three sterilised and pre-germinated tomato seeds were placed into the second compartment of the split Petri dish containing MS medium following the procedure reported above. To assess the effects of pure VOCs on the ability of Ps. putida MVC 17 to release siderophores and solubilise phosphate and potassium, CAS agar, NBRIP or AA medium were poured respectively into the second compartment of the split Petri dish and inoculated with $10 \mu \mathrm{L}$ of Ps. putida MVC 17 as mentioned above. 
Ps. putida MVC 17 or pre-germinated tomato seeds exposed to filter papers wetted with ethanol and methanol respectively were used as untreated controls. For each test, split Petri dishes were sealed with a double layer of parafilm tape and incubated following the timing mentioned above. After each respective incubation period, LRD, tomato root, shoot dry weight, and the ability of Ps. putida MVC 17 to release siderophores, solubilise of phosphate and potassium were evaluated as mentioned above. To determine whether exposure to pure VOC affected the viability of Ps. putida MVC 17 cells, the number of bacterial cells residing in the macrocolony area upon exposure to pure VOC was assessed as mentioned above. Four replicates (split Petri dishes) were used for each treatment and the experiment was repeated.

\subsection{Effect of VOCs Released by Pantoea agglomerans MVC 21 on the Interaction between Pseudomonas putida MVC 17 and Tomato Seedlings}

A volume of $20 \mu \mathrm{L}$ of $P$. agglomerans MVC 21 cell suspension was spot-inoculated onto NA ( $25 \mathrm{~mL})$ contained in one compartment of split Petri dish. Subsequently, dishes were sealed as reported above and incubated at $25^{\circ} \mathrm{C}$. After $48 \mathrm{~h}$, germinated tomato seeds were inoculated with one $\mathrm{mL}$ of Ps. putida MVC 17 cell suspension according to the procedure described by [33]. Once inoculated, three tomato seeds were placed into the compartment of split Petri dishes containing MS (25 mL). Split Petri dishes having the compartment containing NA not inoculated with P. agglomerans MVC 21 and the compartment with MS containing tomato seeds inoculated with Ps. putida MVC 17 were used as untreated control. Dishes were sealed with a double layer of Parafilm tape and incubated in the growth chamber as reported above. After 10 days, plant fresh weight, LRD, and plant dry weight were determined. Four replicates (split Petri dishes) were used for each treatment and the experiment was repeated.

\subsection{Evaluation of the Effect of Dimethyl Disulfide and Volatile Organic Compounds Emitted by Pantoea agglomerans MVC 21 on the Production of Indole-3-Acetic Acid in Pseudomonas putida MVC 17}

IAA production was evaluated according to the procedure described by [33] with modifications. A volume of $20 \mu \mathrm{L}$ of P. agglomerans MVC 21 cell suspension was added into one well of 25-well polystyrene plates (Thermo Fisher Scientific, Waltham, MA, USA) containing three $\mathrm{mL}$ of NA. The rest of wells were filled with three $\mathrm{mL}$ of DF salt minimal broth amended with $500 \mu \mathrm{g} / \mathrm{mL}$ of L-Tryptophan (Sigma-Aldrich, USA). In the case of DMDS, a sterilised filter paper was placed into one well of 25-well polystyrene plates and was inoculated with $20 \mu \mathrm{L}$ of a DMDS stock solution (eight $\mathrm{mg} / \mathrm{mL}$ ) to have a final concentration equivalent to $0.02 \mathrm{mg} /$ Petri dish, assuming the complete evaporation of the VOC from the filter paper. Subsequently, the 25-well polystyrene plates were introduced in Petri dishes (150 mm diameter) and sealed with doubled layer of Parafilm tape and kept in the incubator at $25^{\circ} \mathrm{C}$. After 2 days incubation, a volume of $300 \mu \mathrm{L}$ of Ps. putida MVC 17 cell suspension was added to wells containing DF salt minimal broth (three $\mathrm{mL}$ ) amended with $500 \mu \mathrm{g} / \mathrm{mL}$ of L-Tryptophan. Petri dishes were sealed with a double layer of Parafilm tape and incubated at $28^{\circ} \mathrm{C}$ on an orbital shaker (200 rpm). As untreated controls, 25-well polystyrene plates with wells containing non-inoculated NA and/or sterile filter papers were used. After $120 \mathrm{~h}$, the quantity of IAA produced by bacterial cells was monitored

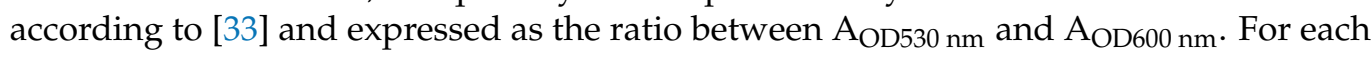
treatment, six replicates (25-well polystyrene plates) were used and the experiment was repeated.

\subsection{Statistical Analysis}

All experiments were carried out twice. Normality (Shapiro-Wilk test, $p>0.05$ ) and variance homogeneity (Levene's test, $p>0.05$ ) were checked and parametric tests were used. Non-significant differences were found between two experiments $(p>0.05)$ after two-way ANOVA and thus, data from experiments were pooled. Data were subsequently analysed using one-way ANOVA and mean comparisons between treatments were assessed by 
Tukey's test $(\alpha=0.05)$. The statistical analysis was performed using IBM SPSS software (Version 21).

\section{Results}

\subsection{Compatibility between Pantoea agglomerans MVC 21 and Pseudomonas putida MVC 17}

A first set of experiments was carried out to evaluate if P. agglomerans MVC 21 and Ps. putida MVC 17 might coexist in the same ecological niche. No toxic effect was detected in the compatibility test carried out in not split Petri dishes. Instead, P. agglomerans MVC 21 and Ps. putida MVC 17 cell density increased significantly when they interacted, compared to when they grew alone (Figure S2A). Similarly, no negative effect of VOCs emitted by $P$. agglomerans MVC 21 and Ps. putida MVC 17 was observed on either bacteria, when they interacted in split Petri dishes (Figure S2B).

\subsection{Interaction with Pantoea agglomerans MVC 21 Modulates the Plant Growth-Promoting Activities of Pseudomonas putida MVC 17}

Once assessed the compatibility, experiments were designed to investigate if and how the two bacterial strains might modulate their plant growth-promoting activities during the interaction.

Firstly, no negative effect of VOCs on P. agglomerans MVC 21 and Ps. putida MVC 17 cell viability was observed in these experiments (Figure S3). In not split Petri dishes, PS. putida MVC 17 significantly increased (19\%) the release of siderophores when interacting with P. agglomerans MVC 21 compared to the untreated control (Figure 1A). However, the co-inoculum significantly decreased the ability of Ps. putida MVC 17 to solubilise phosphate $(17 \%)$ and potassium (43\%) compared to the untreated control (Figure 1B,C). A similar effect was observed with VOCs emitted by P. agglomerans MVC 21 that significantly increased the ability of Ps. putida MVC 17 to release siderophores (6\%) compared to the untreated control (Figure 1D). Conversely, P. agglomerans MVC 21 VOCs caused a significant decrease in the ability of Ps. putida MVC 17 to solubilise phosphate (47\%) and potassium (35\%) compared to the untreated control (Figure 1E,F). Differently, Ps. putida MVC 17 did not affect the plant growth-promoting activities of P. agglomerans MVC 21 compared to the untreated control in both experiments carried out in not split and split Petri dishes (Figure 1A-F).
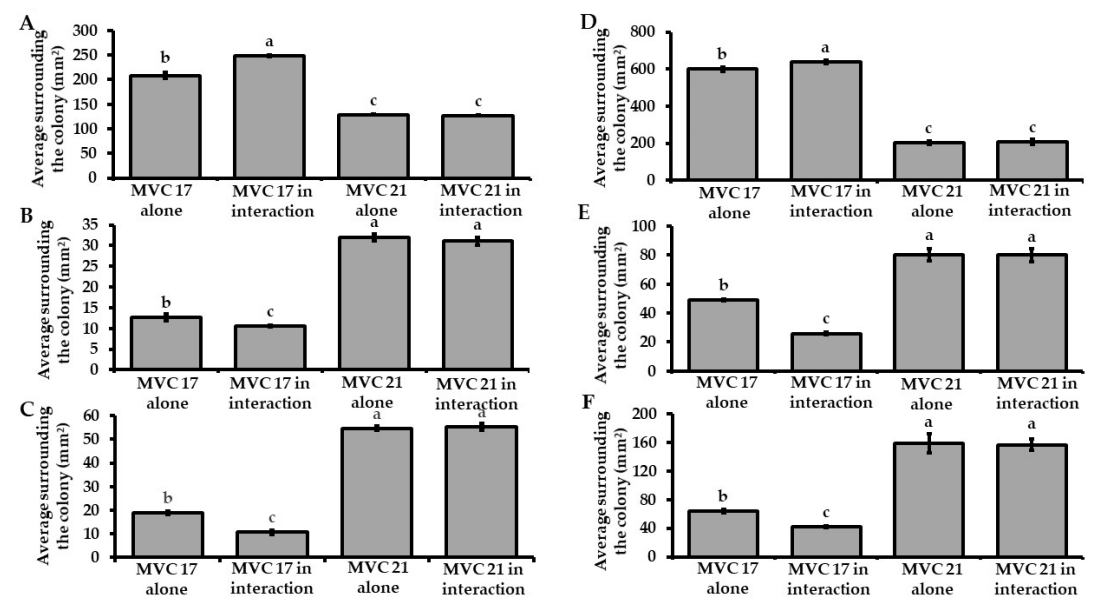

Figure 1. Effect of bacterial interaction on plant growth-promoting activities. Assessment of the ability of Pantoea agglomerans MVC 21 and Pseudomonas (Ps.) putida MVC 17 to release siderophores $(\mathbf{A}, \mathbf{D})$ and to solubilise phosphate $(\mathbf{B}, \mathbf{E})$ and potassium $(\mathbf{C}, \mathbf{F})$ during the interaction in not split $(\mathbf{A}-\mathbf{C})$ and split Petri (D-F) dishes. MVC 17 alone. halo size of Ps. putida MVC 17 grown alone; MVC 17 in interaction. Halo size of Ps. putida MVC 17 interacting with P. agglomerans MVC 21; MVC 21 alone. halo size of $P$. agglomerans MVC 21 grown alone; MVC 21 in interaction. Halo size of P. agglomerans MVC 21 interacting with Ps. putida MVC 17. Columns represent mean standard error of six replicates (Petri dishes) are reported for each treatment. Data from two independent experiments were pooled. Different letters indicate significant differences among treatments according to Tukey's test $(\alpha=0.05)$. 


\subsection{Pantoea agglomerans MVC 21 Releases VOCs with a Positive Impact on Tomato Seedling Growth}

The evidence that the VOCs released by P. agglomerans MVC 21 modulated the plant growth-promoting activities of Ps. putida MVC 17 lead to investigate how and if VOCs released by the two PGPR might affect the growth of tomato seedlings.

The ability of P. agglomerans MVC 21 and Ps. putida MVC 17 to stimulate plant growth through the release of VOCs was evaluated in split Petri dishes. Upon exposure to Ps. putida MVC 17, no significant changes in LRD, root or shoot biomass were observed (Figure 2A). Conversely, when exposed to P. agglomerans MVC 21 VOCs, tomato seedlings significantly increased the LRD $(125 \%)$, the shoot $(71 \%)$ and root dry weight $(81 \%)$ compared to the seedlings exposed to agar medium only (Figure 2B,C).
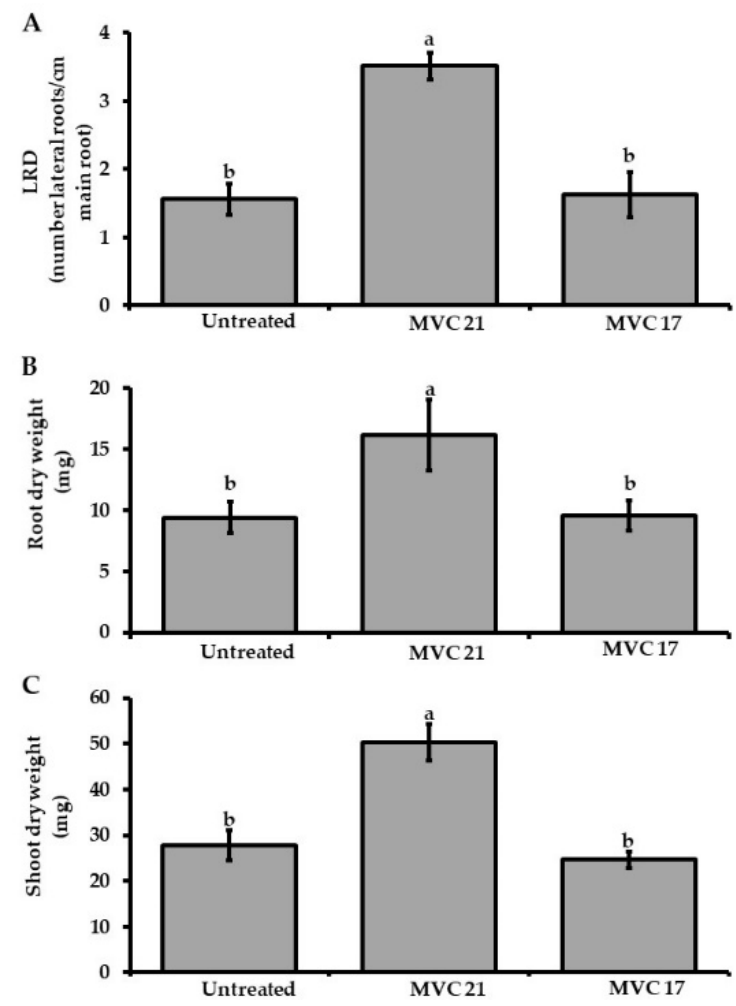

Figure 2. Plant growth-promoting effect of volatile organic compounds (VOCs) emitted by Pantoea agglomerans MVC 21 and Pseudomonas (Ps.) putida MVC 17. Lateral Root Density (LRD) (A), root (B), and shoot (C) dry weight of tomato seedlings were assessed after 10 days of exposure to P. agglomerans MVC 21 and Ps. putida MVC17 VOCs. Untreated. tomato seedlings exposed to agar medium only; MVC 21. tomato seedlings exposed to P. agglomerans MVC 21 VOCs; MVC 17. tomato seedlings exposed to Ps. putida MVC17 VOCs. Columns represent mean \pm standard error values of 12 replicates (tomato seedlings) are reported for each treatment. Data from two independent experiments were pooled. Different letters indicate significant differences among treatments according to Tukey's test $(\alpha=0.05)$.

3.4. Headspace Analysis of VOCs Using GC-MS Only Few VOCs Were Produced at Levels Above the Limit of Detection of the Applied GC-MS Method

Based on the positive effect of VOCs released by P. agglomerans MVC 21 on tomato seedlings, a headspace analysis was carried out to identify the VOCs having a similar positive effect on tomato seedlings. In total, seven VOCs were identified in the volatile profile of P. agglomerans MVC 21 (Table 1). One of them, namely 2-undecanone, was only found in one out of 10 replicate headspace (HS) cultivations. Additionally, some VOCs, namely 2-tridecanone, 2-nonanone, 1-tetradecanol, were found in two and five cultures out of 10, respectively. Three VOCs, namely 2-phenylethyl alcohol (2PEA), 3-methyl-1-butanol 
(3M1B), and dimethyl disulfide (DMDS), were most consistently (10 out of 10 HS vials) detected. After $96 \mathrm{~h}$ of incubation in the HS vial, the estimated amount of each VOC produced by P. agglomerans MVC 21 was $2.1 \mathrm{ng}$ of DMDS, $9600 \mathrm{ng}$ of 3M1B and $91.2 \mathrm{ng}$ of 2PEA (Table 1).

Table 1. Volatile organic compounds (VOCs) detected by gas chromatography-mass spectrometry (GC-MS) in the headspace of vials inoculated with Pantoea agglomerans MVC 21 and incubated for six days.

\begin{tabular}{ccccc}
\hline Metabolite $^{\mathbf{1}}$ & RI $^{\mathbf{2}}$ & Sim Score $^{\mathbf{3}}$ & $\begin{array}{c}\text { Level of } \\
\text { Identification }\end{array}$ & HS Vials $^{\mathbf{5}^{\mathbf{2}}}$ \\
\hline Dimethyl disulfide & 735 & 0.98 & 1 & $10 / 10$ \\
3-Methyl-1-butanol & 752 & 0.99 & 1 & $10 / 10$ \\
2-Phenylethyl-alcohol & 1115 & 0.97 & 1 & $10 / 10$ \\
2-Tridecanone & 1498 & 0.89 & 1 & $5 / 10$ \\
2-Nonanone & 1093 & 0.87 & 1 & $2 / 10$ \\
1-Tetradecanol & 1671 & 0.91 & 1 & $2 / 10$ \\
2-Undecanone & 1295 & 0.87 & 1 & $1 / 10$ \\
\hline
\end{tabular}

${ }^{1}$ VOCs not related to the untreated control. ${ }^{2}$ Average retention index (RI). ${ }^{3}$ Average similarity score $\geq 0.80 .{ }^{4}$ Levels of identification were assigned according to Blaženović et al. (2018) where $1=$ confident identification by comparison of GC-MS spectrum and RI to standard compounds analysed under the same chromatographic and MS conditions. ${ }^{5}$ Number of sample replicates in which the VOC was detected to the total number of replicates analysed.

\subsection{Dimethyl Disulfide Shows a Positive Effect on Pseudomonas putida MVC 17 Plant Growth-Promoting Activities and on Tomato Plant Growth}

Once identified, the main VOCs produced by P. agglomerans MVC 21 were tested to determine the specific effect on Ps. putida MVC 17 plant growth-promoting activities and tomato plant growth. Upon exposure to 2PEA, 3M1B, and DMDS, the number of viable cells in Ps. putida MVC 17 macrocolony did not change compared to the untreated control (Figure S4). 2PEA and 3M1B did not affect Ps. putida MVC 17 plant growth-promoting activities (Tables S1 and S2) whereas DMDS showed modulating activity in a concentrationdependent manner. In particular, DMDS increased the ability of Ps. putida MVC 17 to release siderophores at the highest concentration tested (Table 2). In contrast to this, DMDS decreased the ability of Ps. putida MVC 17 to solubilise phosphate and potassium (17\% and $40 \%$; Table 2).

Table 2. Effect of pure dimethyl disulfide (DMDS) on the plant growth-promoting activities of Pseudomonas (Ps.) putida MVC 17 and tomato plant growth.

\begin{tabular}{|c|c|c|c|}
\hline DMDS Concentration * & Siderophore Release $\left(\mathrm{mm}^{2}\right) * *$ & Phosphate Solubilisation $\left(\mathrm{mm}^{2}\right)$ & Potassium Solubilisation $\left(\mathrm{mm}^{2}\right)$ \\
\hline 0 & $592.10 \pm 2.69 c$ & $27.35 \pm 0.79 \mathrm{a}$ & $76.37 \pm 0.25 \mathrm{a}$ \\
\hline 0.02 & $610.16 \pm 1.25 c$ & $24.77 \pm 0.56 \mathrm{a}$ & $74.34 \pm 0.56 \mathrm{a}$ \\
\hline 0.2 & $612.33 \pm 2.33 c$ & $20.39 \pm 0.36 b$ & $66.18 \pm 0.36 b$ \\
\hline 2 & $675.53 \pm 1.09 \mathrm{~b}$ & $17.21 \pm 0.44 b$ & $65.81 \pm 0.44 b$ \\
\hline 20 & $707.01 \pm 2.45 \mathrm{a}$ & $16.37 \pm 0.74 b$ & $63.30 \pm 0.74 b$ \\
\hline DMDS Concentration * & Lateral Root Density ${ }^{* * *}$ & Rood Dry Weight (mg) & Shoot Dry Weight (mg) \\
\hline 0 & $1.46 \pm 0.05 c$ & $12.32 \pm 0.55 \mathrm{~d}$ & $31.14 \pm 0.92 \mathrm{~d}$ \\
\hline 0.02 & $1.82 \pm 0.03 b$ & $26.43 \pm 1.33 c$ & $53.31 \pm 2.33 c$ \\
\hline 0.2 & $1.94 \pm 0.06 \mathrm{~b}$ & $37.87 \pm 0.21 c$ & $79.25 \pm 1.25 c$ \\
\hline 2 & $2.31 \pm 0.12 \mathrm{a}$ & $47.31 \pm 1.23 \mathrm{~b}$ & $84.25 \pm 0.99 b$ \\
\hline 20 & $2.40 \pm 0.16 \mathrm{a}$ & $57.65 \pm 2.36 \mathrm{a}$ & $102.33 \pm 1.22 \mathrm{a}$ \\
\hline
\end{tabular}

The ability of Ps. putida MVC 17 to release siderophores, solubilise phosphate and potassium was assessed after exposure to different concentrations of DMDS. Lateral root density, root, and shoot dry weight were evaluated after 10 days of exposure to different concentrations of pure DMDS. Mean \pm standard error values of six replicates are reported for each treatment in the case of plant growth-promoting activities of Ps. putida MVC17 whereas mean \pm standard error values of 12 replicates (tomato seedlings) are reported for each treatment in the case of tomato plant growth. In both cases, data from two independent experiments were pooled. Different letters indicate significant differences among treatments according to Tukey's test $(\alpha=0.05) .{ }^{*}$ ng/split Petri dish; ${ }^{* *}$ average halo area surrounding the colony; ${ }^{* *}$ number lateral roots $/ \mathrm{cm}$ main root. 
At the tested concentrations, neither 2PEA nor 3M1B had any effect on tomato seedlings (Tables S1 and S2), whereas DMDS showed a significant increase in the LRD (64\%), root $(367 \%)$, and shoot (239\%) dry weight compared to the untreated control (Table 2).

3.6. Dimethyl Disulfide and VOCs Emitted by Pantoea agglomerans MVC 21 Affect the Interaction between Pseudomonas putida MVC17 and Tomato Seedlings

Based on the positive effect of the VOCs released by P. agglomerans MVC 21 on plant growth of tomato seedlings and plant growth-promoting activities of Ps. putida MVC 17, we investigated their effect on the interaction between tomato seedlings and Ps. putida MVC 17. Tomato seedlings inoculated with Ps. putida MVC 17 significantly increased LRD compared to the untreated control and tomato seedling exposed to P. agglomerans MVC 21 VOCs. In contrast, Ps. putida MVC 17 did not increase the root dry weight (Figure 3). As reported above, Ps. putida MVC 17 had no positive effect on tomato seedling growth, whereas P. agglomerans MVC 21 significantly increased tomato LRD and root dry weight compared to the untreated control (Figure 2). Notably, tomato seedlings inoculated with Ps. putida MVC 17 and exposed to P. agglomerans MVC 21 VOCs significantly increased the LRD and the root dry biomass compared to the untreated control and other treatments (Figure 3A,B).
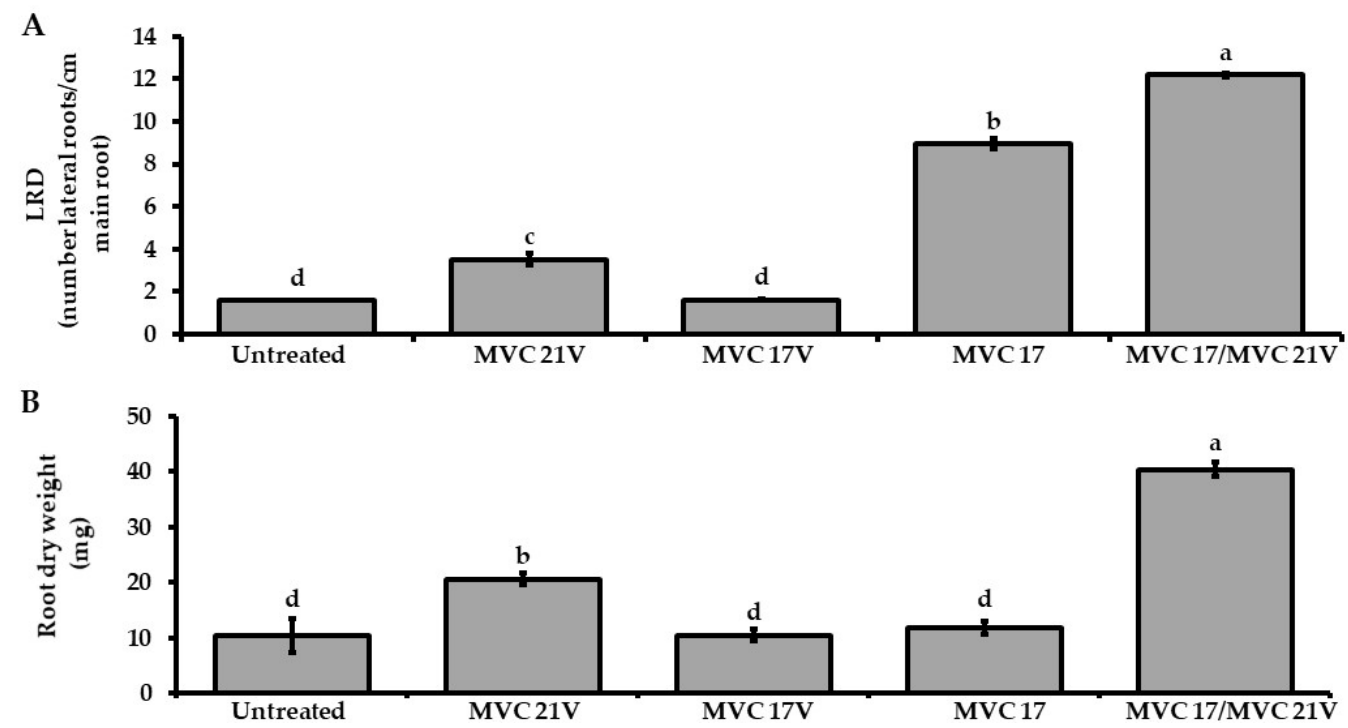

Figure 3. Effect of Pantoea agglomerans MVC 21 volatile organic compounds (VOCs) on the plant growth-promoting efficacy of Pseudomonas (Ps.) putida MVC 17. Lateral root density (LRD) (A) and root dry weight (B) of tomato seedlings inoculated with Ps. putida MVC 17 were assessed after 10 days of exposure to P. agglomerans MVC 21 VOCs. Untreated. tomato seedlings exposed to agar medium only; MVC 21V. tomato seedlings exposed to P. agglomerans MVC 21 VOCs; MVC 17V. tomato seedlings exposed to Ps. putida MVC 17 VOCs; MVC 17. tomato seedlings inoculated with Ps. putida MVC 17; MVC 17/MVC 21V. tomato seedlings inoculated with Ps. putida MVC 17 and exposed to $P$. agglomerans MVC 21 VOCs. Columns represent mean \pm standard error values of twelve replicates (tomato seedlings) are reported for each treatment. Data from two independent experiments were pooled. Different letters indicate significant differences among treatments according to Tukey's test $(\alpha=0.05)$.

3.7. Dimethyl Disulfide and VOCs Emitted by Pantoea agglomerans MVC 21 Show a Positive Effect on the Production of Indole-3-Acetic Acid by Pseudomonas putida MVC 21

As VOCs released by P. agglomerans MVC 21 positively influenced the interaction between Ps. putida MVC 17 and tomato seedlings, a set of experiments were designed to determine if and how P. agglomerans MVC 21 VOCs and DMDS might influence IAA production by Ps. putida MVC 17. VOCs emitted by P. agglomerans MVC 21 positively affected the production of IAA (29\%) by Ps. putida MVC 17 compared to the untreated 
control (Figure 4). Similarly, DMDS positively modulated the production of IAA by Ps. putida MVC 17. Particularly, the application of DMDS at $0.02 \mathrm{mg} /$ Petri dish increased the production of IAA by $180 \%$ (Figure 4).

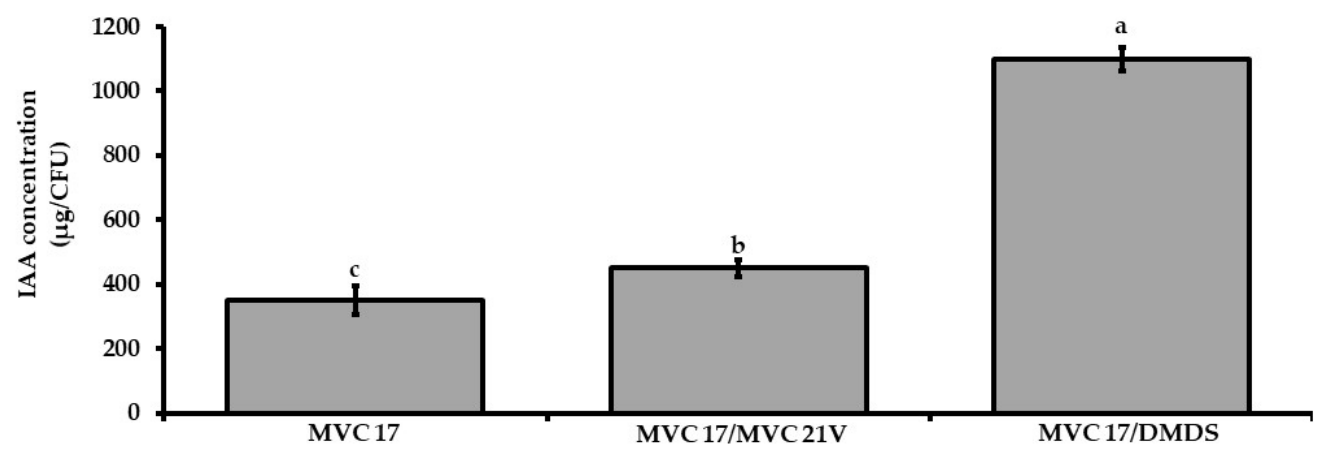

Figure 4. Effect of interaction mediated by volatile organic compounds (VOCs) on indol-3-acetic acid production by Pseudomonas (Ps.) putida MVC 17. The effect of VOCs emitted by P. agglomerans MVC 21 and of dimethyl disulfide (DMDS) on the ability of Ps. putida MVC 17 to produce indole-3-acetic acid (IAA) was assessed after $120 \mathrm{~h}$ of incubation in DF salt amended with L-Tryptophan. MVC 17 alone. IAA production of Ps. putida MVC 17 grown alone; MVC 17/MVC 21V. IAA production of Ps. putida MVC 17 exposed to P. agglomerans MVC 21 VOCs. MVC 17/DMDS. IAA production of Ps. putida MVC 17 exposed to DMDS at $0.02 \mathrm{mg} / 25$ well plate. Columns represent mean \pm standard error values of six replicates for each treatment. Data from two independent experiments were pooled. Different letters indicate significant differences among treatments according to Tukey's test $(\alpha=0.05)$.

\section{Discussion}

Soil bacteria coexist in complex multispecies communities where VOCs play an important role in the interactions among the various microorganisms. In fact, VOCs not only act as antimicrobials by suppressing other microorganisms competing for the same ecological niche, but also as chemical signals, affecting behavior and gene expression of responding microorganisms [43].

Under greenhouse conditions, P. agglomerans MVC 21 and Ps. putida MVC 17 promote tomato plant growth [33], therefore in this work we aimed at understanding how these PGPR interact among themselves and with tomato seedlings, and how the interaction between the two PGPR may affect the development of tomato seedlings. Firstly, we proved that neither P. agglomerans MVC 21 nor Ps. putida MVC 17 released any diffusible toxic metabolite or VOC against the other. In fact, the number of P. agglomerans MVC 21 and Ps. putida MVC 17 viable cells present in interacting macrocolonies grown in not split Petri dishes were even higher compared to monocultures, whereas cell numbers were not significantly differing in the case of split Petri dishes. These results suggest that these two PGPR might coexist under natural conditions and share the same ecological niches when applied in the field. From a practical point of view, this information indicates that these two strains may be combined in a biostimulant product, as already reported for a combination of other PGPR belonging to P. agglomerans and Ps. putida [44]. From an ecological point of view, our results confirm previous evidences of how members of the genus Pantoea and Pseudomonas may coexist and interact in the phytobiome. In fact, it was already shown that P. agglomerans strains were associated with Ps. savastanoi pv. savastanoi, the causal agent of olive (Olea europaea L.) knot disease, and their interaction determined the increase of olive knot size [45].

These bacterial species were found to interact through a QS mechanism based on the production of AHLs [46]. In our case, interaction experiments carried out in not split and split Petri dishes indicated that the interaction between P. agglomerans MVC 21 and Ps. putida MVC 17 mainly relied on the ability of P. agglomerans to release VOCs. Particularly, the VOCs emitted by P. agglomerans MVC 21 were able to affect the ability of Ps. putida 
MVC 17 to release siderophores and solubilise phosphate and potassium. VOCs may affect different bacterial traits as cell motility, biofilm formation [47] cell metabolism, cell wall biosynthesis and response to stresses [48]. At the best of our knowledge, this is the first time that VOCs, as a communication signalling system, were shown to modulate plant growth-promoting activities in PGPR.

Notably, other communication signalling systems are controlling plant growth-promoting activities in bacteria. For instance, the AHL system in Paracoccus denitrificans [49], Autoinducer2 (AI-2) system in Actinobacillus actinomycetemcomitans [50] and Porphyromonas gingivalis [51], and the Pseudomonas quinolone signal (PQS) system in Ps. aeruginosa [52] were found to mediate the ability of these bacteria to chelate iron from the environment. Similarly, AHL and AI-2 systems were shown to be involved in phosphorous acquisition in the cyanobacterium Trichodesmium consortia [53]. Given the importance of iron and phosphorous in the physiology of bacterial cells, it is conceivable that different communication signalling systems evolved in bacteria to regulate the uptake of these elements from the environment.

Interestingly, we found that the VOCs emitted by P. agglomerans MVC 21 were also involved in the establishment of a positive interaction with tomato plants. Indeed, tomato seedlings exposed to P. agglomerans MVC 21 VOCs showed a significant increase in LRD, root and shoot dry weight compared to the untreated control and the ones exposed to Ps. putida MVC 17 VOCs. The ability of P. agglomerans strains to stimulate plant growth through production of siderophores, phytohormones, and solubilisation of phosphate is widely accepted [54-58]. In contrast, investigation on the involvement of VOCs produced by $P$. agglomerans in plant growth promotion is still in its infancy. However, the genome sequencing of plant beneficial P. agglomerans strains highlighted the presence of genes being putatively involved in the biosynthesis of VOCs that may stimulate plant growth [54,59]. Moreover, [27] found that the endophyte P. agglomerans E44 was able to stimulate seed germination and increase primary root length as well as fresh biomass of wild cabbage seedlings.

VOCs released by P. agglomerans E44 belong to the family of alkenes (1-undecene, cyclohexane), sulfides (DMDS and dimethyl trisulfide), and terpenes such as alpha-pinene [27]. In our case, $P$. agglomerans MVC 21 released VOCs belonging to the family of alcohols, ketones and sulfide. More specifically, 2PEA, 3M1B, and DMDS were the VOCs detected in the headspace of all of the tested culture replicates of P. agglomerans MVC 21. Furthermore, bioassays testing the effect of pure VOCs indicates that DMDS is the main active VOC released by $P$. agglomerans MVC 21, able to modulate the plant growth-promoting activities of Ps. putida MVC 17 and to stimulate the growth of tomato seedlings in a dose-dependent manner.

Volatile sulfide compounds, such as DMDS, dimethyl sulfide and dimethyl trisulfide play an important role in plant-microbe and interspecific microbe-microbe interactions $[30,60]$. DMDS is produced by several bacteria as Bacillus sp., Pantoea sp., Pseudomonas sp., Serratia sp., and Stenotrophomonas sp. $[42,43,61]$. It is also the main volatile produced by Serratia plymuthica IC1270 that suppressed the growth of Agrobacterium strains [62]. However, little is known on the impact of DMDS on the production of siderophores and solubilisation of phosphate and potassium by PGPR. Our results showed that DMDS, similarly to $P$. agglomerans MVC 21 VOCs, significantly affected plant growth-promoting activities in Ps. putida MVC 17. As DMDS did not show any effect on the viability of Ps. putida MVC 17 cells, it is probable that this VOC may modulate expression of genes associated to plant growthpromoting activities, acting as an interspecies signal that allows bacteria to coordinate their behaviour according to neighbouring communities. In the future, transcriptome analysis of rhizosphere associated bacteria might be carried out to understand how DMDS affects their behaviour.

DMDS was the main active compound released by P. agglomerans MVC 21 responsible for the promotion of tomato seedlings in a concentration-dependent manner. Interestingly, after exposure to VOCs emitted by P. agglomerans MVC 21 and/or pure DMDS, tomato seedlings increased their LRD, as well as root and shoot biomass. DMDS may inhibit 
plant growth when applied at high concentrations; whereas it may inhibit plant pathogens and induce plant systemic resistance when used at low concentrations [63-65]. DMDS produced by Burkholderia ambifaria increased Arabidopsis thaliana biomass, resistance to gentamicin and kanamycin in Escherichia coli and inhibited Alternaria alternata and Rhizoctonia solani growth [66]. Similar to other VOCs, DMDS may modulate root system architecture by affecting plant hormone biosynthesis. Indeed, indole and DMDS promoted root development by modulating auxin signalling pathways in A. thaliana. In particular, DMDS strongly enhanced auxin signalling near the root apical meristem $[67,68]$. Thus, we can hypothesize that $P$. agglomerans MVC 21 VOCs and DMDS had a similar effect by promoting auxin biosynthesis in tomato seedlings in our system.

As both DMDS and VOCs released by P. agglomerans MVC 21 influenced the activities of Ps. putida MVC 17 and the growth of tomato seedlings, we hypothesized that they might also influence the interaction between the plant and bacterium. Strikingly, our results showed that VOCs released by P. agglomerans MVC 21 positively influenced this interaction by boosting the plant growth-promoting efficacy of Ps. putida MVC 17. Indeed, tomato seedlings interacting with Ps. putida MVC 17 and exposed to VOCs released by P. agglomerans MVC 21 showed a significant increase of LRD and root dry weight. These results lead us to hypothesize that, similarly to what is reported in plants [68], DMDS and P. agglomerans VOCs might also have a promoting effect on indole-3-acetic acid production in bacteria. Our results clearly showed that DMDS and P. agglomerans VOCs enhanced indole-3-acetic acid production in Ps. putida MVC 17, providing thus the first evidence of DMDS to be a VOC signal that is able to affect the same biosynthetic pathway in two kingdoms.

In conclusion, this work suggests that VOCs and, in particular, DMDS emitted by $P$. agglomerans species have an ecological role in the rhizosphere. In fact, VOCs released by $P$. agglomerans may act as chemical signals by modulating the behaviour of tomato plants as well as PGPR belonging to the species Ps. putida, even when far from each other. In future, mutants of P. agglomerans MVC 21 impaired in VOC production and/or unable to release DMDS might be created to better determine the role played by these compounds in the interaction between P. agglomerans, PGPR and crop plants. From a practical point of view, our results show that DMDS, used as a commercial soil fumigant for the control of plant pathogens [18], may stimulate also plant growth and improve the interaction between plants and PGPR residing in agricultural soils.

Supplementary Materials: The following are available online at https: / /www.mdpi.com/article / 10.3390/microorganisms9061186/s1, Figure S1: Experimental design used to investigate on the interaction between Pantoea agglomerans MVC 21 and Pseudomonas (Ps.) putida MVC 17; Figure S2: Compatibility between Pantoea agglomerans MVC 21 and Pseudomonas (Ps.) putida MVC 17; Figure S3: Viability of Pseudomonas (Ps.) putida MVC 17 cells after exposure to Pantoea agglomerans MVC 21 volatile organic compounds (VOCs); Figure S4: Effect of pure 3-metyl-1-butanol (3M1B), 2-phenylethyl alcohol (2PEA) and dimethyl disulfide (DMDS) on the viability of Pseudomonas (Ps.) putida MVC 17 cells.

Author Contributions: Conceptualization, M.V.-C. and G.P.; Data curation, M.V.-C.; Formal analysis, M.V.-C. and G.P.; Funding acquisition, M.V.-C., H.D.d.B., R.S., I.P. and G.P.; Investigation, M.V.-C., A.V. and A.P.; Supervision, G.P. and H.D.d.B.; Validation, M.V.-C., A.V. and A.P.; Writing-original draft, M.V.-C.; Writing-review and editing, M.V.-C., A.V., A.P., R.S., H.D.d.B., I.P. and G.P. All authors have read and agreed to the published version of the manuscript.

Funding: This project has received funding from the European Union's Horizon 2020 Research and Innovation Program under the Marie Skłodowska-Curie grant agreement no. 722642 (project INTERFUTURE).

Institutional Review Board Statement: Not applicable.

Informed Consent Statement: Not applicable.

Conflicts of Interest: All the authors declare any conflicts of interest. 


\section{References}

1. Bakker, P.A.H.M.; Berendsen, R.L.; Doornbos, R.F.; Wintermans, P.C.A.; Pieterse, C.M.J. The rhizosphere revisited: Root microbiomics. Front. Plant Sci. 2013, 4, 1-7. [CrossRef]

2. Mendes, R.; Garbeva, P.; Raaijmakers, J.M. The rhizosphere microbiome: Significance of plant beneficial, plant pathogenic, and human pathogenic microorganisms. FEMS Microbiol. Rev. 2013, 37, 634-663R. [CrossRef]

3. Raaijmakers, J.M.; Paulitz, T.C.; Steinberg, C.; Alabouvette, C.; Moënne-Loccoz, Y. The rhizosphere: A playground and battlefield for soilborne pathogens and beneficial microorganisms. Plant Soil 2009, 321, 341-361. [CrossRef]

4. Leach, J.E.; Triplett, L.R.; Argueso, C.T.; Trivedi, P. Communication in the Phytobiome. Cell 2017, 169, 587-596. [CrossRef]

5. Venturi, V.; Keel, C. Signalling in the Rhizosphere. Trends Plant Sci. 2016, 21, 187-198. [CrossRef]

6. Waters, C.M.; Bassler, B.L. Quorum sensing: Cell-to-cell communication in bacteria. Annu Rev Cell Dev. Biol. 2005, 21, 319-346. [CrossRef] [PubMed]

7. Fuqua, W.C.; Winans, S.C. A LuxR-LuxI type regulatory system activates Agrobacterium Ti plasmid conjugal transfer in the presence of a plant tumor metabolite. J. Bacteriol. 1994, 176, 2796-2806. [CrossRef] [PubMed]

8. Maddula, V.S.; Zhang, Z.; Pierson, E.A.; Pierson, L.S., III. Quorum sensing and phenazines are involved in biofilm formation by Pseudomonas chlororaphis (aureofaciens) strain 30-84. Microb. Ecol. 2006, 52, 289-301. [CrossRef] [PubMed]

9. Pierson, E.A.; Wood, D.W.; Cannon, J.A.; Blachere, F.M.; Pierson, L.S., III. Interpopulation signaling via N-acyl-homoserine lactone among bacteria in the wheat rhizosphere. Mol. Plant Microbe Interact. 1998, 11, 1078-1084. [CrossRef]

10. Evans, K.C.; Benomar, S.; Camuy-Vélez, L.A.; Nasseri, E.B.; Wang, X.; Neuenswander, B.; Chandler, J.R. Quorum-sensing control of antibiotic resistance stabilizes cooperation in Chromobacterium violaceum. ISME J. 2018, 12, 1263-1272. [CrossRef]

11. Lloyd, D.G.; Whitworth, D.E. The myxobacterium Myxococcus xanthus can sense and respond to the quorum signals secreted by potential prey organisms. Front. Microbiol. 2017, 8, 439. [CrossRef]

12. Venturi, V.; Fuqua, C. Chemical signaling between plants and plant-pathogenic bacteria. Annu Rev Phytopathol 2013, 51, 17-37. [CrossRef]

13. Fuqua, C.; Parsek, M.R.; Greenberg, E.P. Regulation of gene expression by cell-to-cell communication: Acyl-homoserine lactone quorum sensing. Annu. Rev. Genet. 2001, 35, 439-468. [CrossRef]

14. Abisado, R.G.; Benomar, S.; Klaus, J.R.; Dandekar, A.A.; Chandler, J.R. Bacterial quorum sensing and microbial community interactions. mBio 2018, 9, e02331-17. [CrossRef]

15. Nawaz, M.S.; Arshad, A.; Rajput, L.; Fatima, K.; Ullah, S.; Ahmad, M.; Imran, A. Growth-stimulatory effect of quorum sensing signal molecule n-acyl-homoserine lactone-producing multi-trait Aeromonas spp. on wheat genotypes under salt stress. Front Microbiol. 2020, 11, 553621. [CrossRef]

16. Schenk, S.T.; Stein, E.; Kogel, K.H.; Schikora, A. Arabidopsis growth and defense are modulated by bacterial quorum sensing molecules. Plant Signal Behav. 2012, 7, 178-181. [CrossRef]

17. Schikora, A.; Schenk, S.T.; Stein, E.; Molitor, A.; Zuccaro, A.; Kogel, K.H. N-acyl-homoserine lactone confers resistance toward biotrophic and hemibiotrophic pathogens via altered activation of AtMPK6. Plant Physiol. 2011, 157, 1407-1418. [CrossRef]

18. Schulz-Bohm, K.; Martín-Sánchez, L.; Garbeva, P. Microbial volatiles: Small molecules with an important role in intra- and inter-kingdom interactions. Front Microbiol. 2017, 8, 1-10. [CrossRef]

19. Schulz, S.; Dickschat, J.S. Bacterial volatiles: The smell of small organisms. Nat. Prod. Rep. 2007, 24, 814-842. [CrossRef]

20. Audrain, B.; Farag, M.A.; Ryu, C.M.; Ghigo, J.M. Role of bacterial volatile compounds in bacterial biology. FEMS Microbiol. Rev. 2015, 39, 222-233. [CrossRef]

21. Zhang, H.; Kim, M.S.; Krishnamachari, V.; Payton, P.; Sun, Y.; Grimson, M.; Farag, M.A.; Ryu, C.-M.; Allen, R.; Melo, I.S.; et al. Rhizobacterial volatile emissions regulate auxin homeostasis and cell expansion in Arabidopsis. Planta 2007, 226, 839-851. [CrossRef]

22. Aziz, M.; Nadipalli, R.K.; Xie, X.; Sun, Y.; Surowiec, K.; Zhang, J.L.; Paré, P.W. Augmenting sulfur metabolism and herbivore defense in Arabidopsis by bacterial volatile signaling. Front. Plant Sci. 2016, 27, 1-14. [CrossRef]

23. Zhang, H.; Sun, Y.; Xie, X.; Kim, M.S.; Dowd, S.E.; Paré, P.W. A soil bacterium regulates plant acquisition of iron via deficiencyinducible mechanisms. Plant J. 2006, 58, 568-577. [CrossRef] [PubMed]

24. Lee, B.; Farag, M.A.; Park, H.B.; Kloepper, J.W.; Lee, S.H.; Ryu, C.M. Induced Resistance by a Long-Chain Bacterial Volatile: Elicitation of Plant Systemic Defense by a C13 Volatile Produced by Paenibacillus polymyxa. PLoS ONE 2012, 7, 1-11. [CrossRef] [PubMed]

25. Zhang, H.; Kim, M.S.; Sun, Y.; Dowd, S.E.; Shi, H.; Paré, P.W. Soil bacteria confer plant salt tolerance by tissue-specific regulation of the sodium transporter HKT1. Mol. Plant Microbe Interact. 2008, 21, 737-744. [CrossRef] [PubMed]

26. Zhang, H.; Xie, X.; Kim, M.S.; Kornyeyev, D.A.; Holaday, S.; Paré, P.W. Soil bacteria augment Arabidopsis photosynthesis by decreasing glucose sensing and abscisic acid levels in planta. Plant J. 2008, 56, 264-273. [CrossRef]

27. Tyc, O.; Putra, R.; Gols, R.; Harvey, J.A.; Garbeva, P. The ecological role of bacterial seed endophytes associated with wild cabbage in the United Kingdom. Microbiol. Open 2020, 9, 1-19. [CrossRef] [PubMed]

28. Lee, J.H.; Wood, T.K.; Lee, J. Roles of indole as an interspecies and interkingdom signaling molecule. Trends Microbiol. 2015, 23, 707-718. [CrossRef]

29. Wang, D.; Ding, X.; Rather, P.N. Indole can act as an extracellular signal in Escherichia coli. J. Bacteriol. 2001, 183, 4210-4216. [CrossRef] 
30. Garbeva, P.; Hordijk, C.; Gerards, S.; de Boer, W. Volatile-mediated interactions between phylogenetically different soil bacteria. Front. Microbiol. 2014, 5, 1-9. [CrossRef]

31. Raio, A.; Brilli, F.; Baraldi, R.; Neri, L.; Puopolo, G. Impact of spontaneous mutations on physiological traits and biocontrol activity of Pseudomonas chlororaphis M71. Microbiol. Res. 2020, 239, 126517. [CrossRef]

32. Tyc, O.; van den Berg, M.; Gerards, S.; Van Veen, J.A.; Raaijmakers, J.M.; de Boer, W.; Garbeva, P. Impact of interspecific interactions on antimicrobial activity among soil bacteria. Front. Microbiol. 2014, 5, 1-10. [CrossRef]

33. Vasseur-Coronado, M.; Dupré du Boulois, H.; Pertot, I.; Puopolo, G. Selection of plant growth promoting rhizobacteria sharing suitable features to be commercially developed as biostimulant products. Microbiol. Res. 2021, 245, 126672. [CrossRef] [PubMed]

34. Murashige, T.; Skoog, F. A revised medium for rapid growth and bio assays with tobacco tissue cultures. Physiol. Plant 1962, 15, 474-497. [CrossRef]

35. Schneider, C.A.; Rasband, W.S.; Eliceiri, K.W. NIH Image to ImageJ: 25 years of image analysis. Nat. Methods 2012, 9, 671-675. [CrossRef] [PubMed]

36. Cordovez, V.; Schop, S.; Hordijk, K.; Dupré de Boulois, H.; Coppens, F.; Hanssen, I.; Raaijmakers, J.M.; Carrión, V. Priming of plant growth promotion by volatiles of root-associated Microbacterium spp. Appl. Environ. Microbiol. 2018, 84, e01865-18. [CrossRef]

37. Lazazzara, V.; Perazzolli, M.; Pertot, I.; Biasioli, F.; Puopolo, G.; Cappellin, L. Growth media affect the volatilome and antimicrobial activity against Phytophthora infestans in four Lysobacter type strains. Microbiol. Res. 2017, 201, 52-62. [CrossRef] [PubMed]

38. Vlassi, A.; Nesler, A.; Perazzolli, M.; Lazazzara, V.; Büschl, C.; Parich, A.; Puopolo, G.; Schuhmacher, R. Volatile organic compounds from Lysobacter capsici AZ78 as potential candidates for biological control of soilborne plant pathogens. Front. Microbiol. 2020, 1, 1748. [CrossRef]

39. Hiller, K.; Hangebrauk, J.; Jäger, C.; Spura, J.; Schreiber, K.; Schomburg, D. Metabolite detector: Comprehensive analysis tool for targeted and nontargeted GC/MS based metabolome analysis. Anal Chem. 2009, 81, 3429-3439. [CrossRef] [PubMed]

40. Blaženović, I.; Kind, T.; Ji, J.; Fiehn, O. Software tools and approaches for compound identification of LC-MS/MS data in metabolomics. Metabolites 2018, 8, 23. [CrossRef] [PubMed]

41. Schmidt, R.; Etalo, D.W.; Jager, V.; de Gerards, S.; Zweers, H.; de Boer, W.; Garbeva, P. Microbial small talk: Volatiles in fungal-bacterial interactions. Front. Microbiol. 2016, 6, 1-12. [CrossRef] [PubMed]

42. Meldau, D.G.; Meldau, S.; Hoang, L.H.; Underberg, S.; Wünsche, H.; Baldwin, I.T. DMDS produced by the naturally associated bacterium Bacillus sp B55 promotes Nicotiana attenuata growth by enhancing sulfur nutrition. Plant Cell 2013, 25, 2731-2747. [CrossRef] [PubMed]

43. Tyc, O.; Song, C.; Dickschat, J.S.; Vos, M.; Garbeva, P. The ecological role of volatile and soluble secondary metabolites produced by soil bacteria. Trends Microbiol. 2017, 25, 280-292. [CrossRef] [PubMed]

44. Malboobi, M.A.; Behbahani, M.; Madani, H.; Owlia, P.; Deljou, A.; Yakhchali, B.; Moradi, M.; Hassanabadi, H. Performance evaluation of potent phosphate solubilizing bacteria in potato rhizosphere. World J. Microbiol. Biotechnol. 2009, 25, 1479-1484. [CrossRef]

45. Marchi, G.; Sisto, A.; Cimmino, A.; Andolfi, A.; Cipriani, M.G.; Evidente, A.; Surico, G. Interaction between Pseudomonas savastanoi pv. savastanoi and Pantoea agglomerans in olive knots. Plant Pathol. 2006, 55, 614-624. [CrossRef]

46. Hosni, T.; Moretti, C.; Devescovi, G.; Suarez-Moreno, Z.R.; M’ Barek, F.; Guarnaccia, C.; Pongor, S.; Onofri, A.; Buonaurio, R.; Venturi, V. Sharing of quorum-sensing signals and role of interspecies communities in a bacterial plant disease. ISME J. 2011, 5, 1857-1870. [CrossRef] [PubMed]

47. Kim, K.S.; Lee, S.; Ryu, C.M. Interspecific bacterial sensing through airborne signals modulates locomotion and drug resistance. Nat. Commun. 2013, 4,1-12. [CrossRef] [PubMed]

48. Molina-Santiago, C.; Daddaoua, A.; Fillet, S.; Duque, E.; Ramos, J.L. Interspecies signalling: Pseudomonas putida efflux pump $\mathrm{TtgGHI}$ is activated by indole to increase antibiotic resistance. Environm. Microbiol. 2014, 16, 1267-1281. [CrossRef]

49. Zhang, Y.; Gao, J.; Wang, L.; Liu, S.; Bai, Z.; Zhuang, X.; Zhuang, G. Environmental adaptability and quorum sensing: Iron uptake regulation during biofilm formation by Paracoccus denitrificans. Appl. Environ. Microb. 2018, 84, 1-15. [CrossRef]

50. Fong, K.P.; Gao, L.; Demuth, D.R. luxS and arcB control aerobic growth of Actinobacillus actinomycetemcomitans under iron limitation. Infect Immun. 2003, 71, 298-308. [CrossRef]

51. James, C.E.; Hasegawa, Y.; Park, Y.; Yeung, V.; Tribble, G.D.; Kuboniwa, M.; Demuth, D.R.; Lamont, R.J. LuxS involvement in the regulation of genes coding for hemin and iron acquisition systems in Porphyromonas gingivalis. Infect. Immun. 2006, 74, 3834-3844. [CrossRef] [PubMed]

52. Bredenbruch, F.; Geffers, R.; Nimtz, M.; Buer, J.; Häussler, S. The Pseudomonas aeruginosa quinolone signal (PQS) has an ironchelating activity. Environ. Microbiol. 2006, 8, 1318-1329. [CrossRef]

53. Van Mooy, B.A.S.; Hmelo, L.R.; Sofen, L.E.; Campagna, S.R.; May, A.L.; Dyhrman, S.T.; Heithoff, A.; Webb, E.A.; Momper, L.; Mincer, T.J. Quorum sensing control of phosphorus acquisition in Trichodesmium consortia. ISME J. 2006, 6, 422-429. [CrossRef] [PubMed]

54. Luziatelli, F.; Ficca, A.G.; Cardarelli, M.; Melini, F.; Cavalieri, A.; Ruzzi, M. Genome sequencing of Pantoea agglomerans C1 provides Insights into molecular and genetics mechanisms of plant growth-promotion and tolerance to heavy metals. Microorganisms 2020 8,153 . [CrossRef] 
55. Malboobi, M.A.; Owlia, P.; Behbahani, M.; Sarokhani, E.; Moradi, S.; Yakhchali, B.; Deljou, A.; Heravi, K.M. Solubilization of organic and inorganic phosphates by three highly efficient soil bacterial isolates. World J. Microbiol. Biotechnol. 2009, 25, 1471-1477. [CrossRef]

56. Omer, Z.S.; Björkman, P.O.; Nicander, B.; Tillberg, E.; Gerhardson, B. 5'-Deoxyisopentenyladenosine and other cytokinins in culture filtrates of the bacterium Pantoea agglomerans. Physiol. Plant. 2004, 121, 439-447. [CrossRef]

57. Quecine, M.C.; Araújo, W.L.; Rossetto, P.B.; Ferreira, A.; Tsui, S.; Lacava, P.T.; Mondin, M.; Azevedo, J.L.; Pizzirani-Kleiner, A.A. Sugarcane growth promotion by the endophytic bacterium Pantoea agglomerans 33.1. Appl. Environ. Microbiol. 2012, 78, 7511-7518. [CrossRef]

58. Viruel, E.; Lucca, M.E.; Siñeriz, F. Plant growth promotion traits of phosphobacteria isolated from Puna, Argentina. Arch. Microbiol. 2011, 193, 489-496. [CrossRef]

59. Shariati, V.; Malboobi, M.A.; Tabrizi, Z.; Tavakol, E.; Owilia, P.; Safari, M. Comprehensive genomic analysis of a plant growthpromoting rhizobacterium Pantoea agglomerans strain P5. Sci. Rep. 2017, 7, 1-12. [CrossRef]

60. Tyc, O.; Zweers, H.; de Boer, W.; Garbeva, P. Volatiles in inter-specific bacterial interactions. Front. Microbiol. 2015, 6, 1-15. [CrossRef]

61. Popova, A.A.; Koksharova, O.A.; Lipasova, V.A.; Zaitseva, J.V.; Katkova-Zhukotskaya, O.A.; Eremina, S.I.; Mironov, A.S.; Chernin, L.S.; Khmel, I.A. Inhibitory and toxic effects of volatiles emitted by strains of Pseudomonas and Serratia on growth and survival of selected microorganisms, Caenorhabditis elegans and Drosophila melanogaster. Biomed. Res. Int. 2014, 1-14. [CrossRef] [PubMed]

62. Dandurishvili, N.; Toklikishvili, N.; Ovadis, M.; Eliashvili, P.; Giorgobiani, N.; Keshelava, R.; Tediashvili, M.; Vainstein, A.; Khmel, I.; Szegedi, E.; et al. Broad-range antagonistic rhizobacteria Pseudomonas fluorescens and Serratia plymuthica suppress Agrobacterium crown gall tumours on tomato plants. J. Appl. Microbiol. 2011, 110, 341-352. [CrossRef] [PubMed]

63. Asari, S.; Matzén, S.; Petersen, M.A.; Bejai, S.; Meijer, J. Multiple effects of Bacillus amyloliquefaciens volatile compounds: Plant growth promotion and growth inhibition of phytopathogens. FEMS Microbiol. Ecol. 2016, 92, 1-11. [CrossRef]

64. Huang, C.J.; Tsay, J.F.; Chang, S.; Yang, H.P.; Wu, W.S.; Chen, C.Y. DMDS is an induced systemic resistance elicitor produced by Bacillus cereus C1L. Pest Manag. Sci. 2012, 68, 1306-1310. [CrossRef] [PubMed]

65. Rojas-Solís, D.; Zetter-Salmón, E.; Contreras-Pérez, M.; Rocha-Granados, M.D.C.; Macías-Rodríguez, L.; Santoyo, G. Pseudomonas stutzeri E25 and Stenotrophomonas maltophilia CR14 endophytes produce antifungal volatile organic compounds and exhibit additive plant growth-promoting effects. Biocatal. Agric. Biotechnol. 2018, 13, 46-52. [CrossRef]

66. Groenhagen, U.; Baumgartner, R.; Bailly, A.; Gardiner, A.; Eberl, L.; Schulz, S.; Weisskopf, L. Production of Bioactive Volatiles by Different Burkholderia ambifaria Strains. J. Chem. Ecol. 2013, 39, 892-906. [CrossRef] [PubMed]

67. Bailly, A.; Groenhagen, U.; Schulz, S.; Geisler, M.; Eberl, L.; Weisskopf, L. The inter kingdom volatile signal indole promotes root development by interfering with auxin signalling. Plant J. 2014, 80, 758-771. [CrossRef] [PubMed]

68. Tyagi, S.; Kim, K.; Cho, M.; Lee, K.J. Volatile DMDS affects root system architecture of Arabidopsis via modulation of canonical auxin signaling pathways. Environ. Sustain. 2019, 2, 211-216. [CrossRef] 